Livability for All in Miami-Dade County, FL

An Age-Friendly Community Survey of

Residents Age 50-Plus

AARP

August 2017

https://doi.org/10.26419/res.00055.025 


\section{Livable Community}

A livable community is one that is safe and secure, has affordable and appropriate housing and transportation options, and offers supportive community features and services. Once in place, those resources enhance personal independence; allow residents to age in place; and foster residents' engagement in the community's civic, economic, and social life.

- AARP Policy Book, Chapter 9

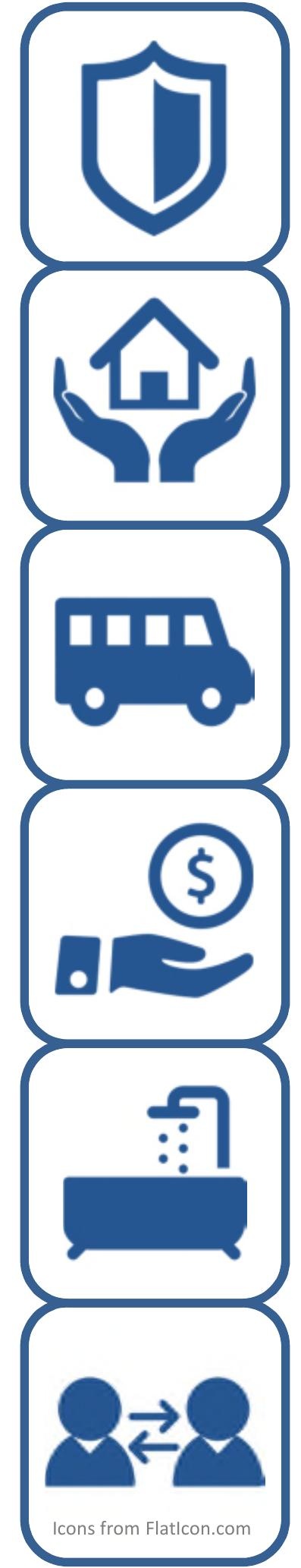




\section{AARP Network of Age-Friendly Communities}

- AARP's Age-Friendly Network is an affiliate of the World Health Organization (WHO) Global Network of Age-Friendly Cities and Communities Program.

- The program was established to connect cities, communities and organizations worldwide with the common vision of making their community a great place where people can grow up and grow old.

- The program targets the environmental, social, and economic factors that influence the health and well-being of residents of all ages.

\section{The WHO 8 Domains of Livability}
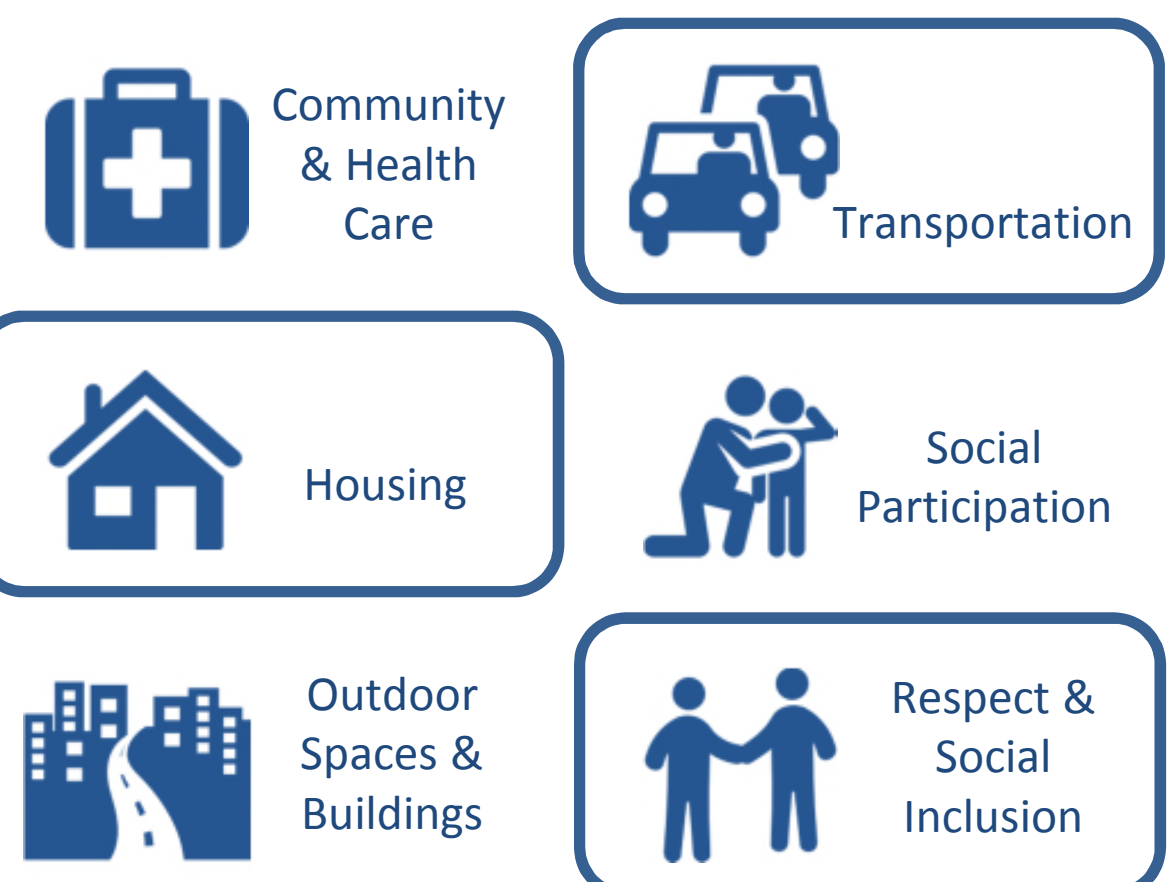

Outdoor

Spaces \&

Buildings
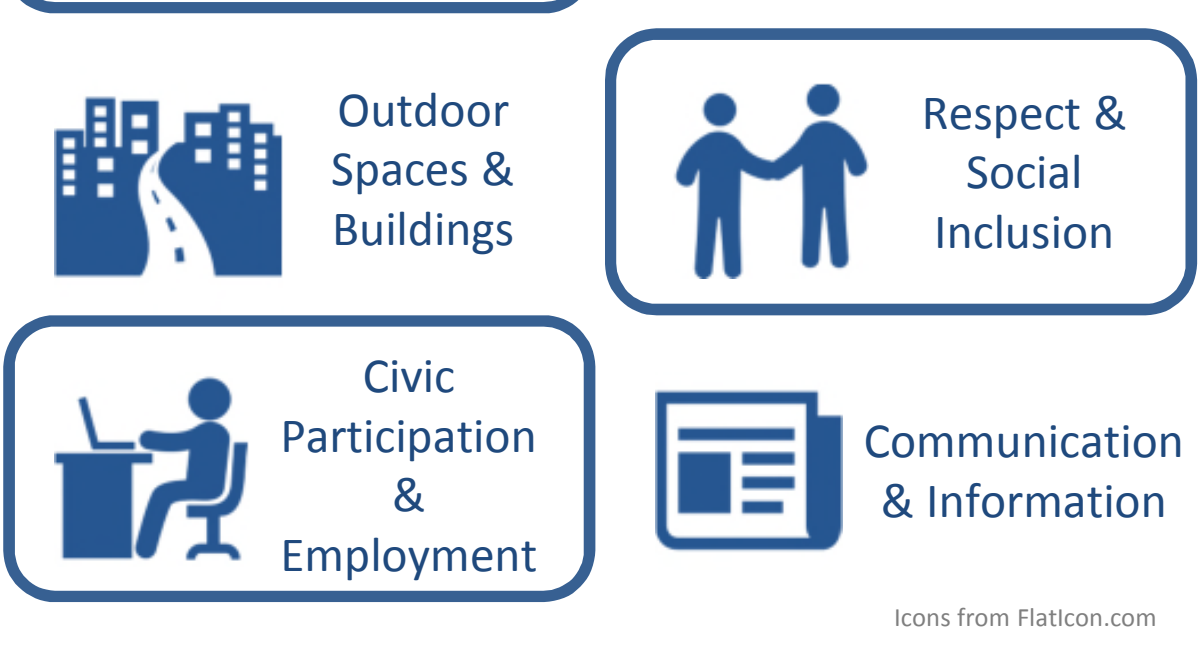


\section{Top Community Features}

(\% Excellent/Very Good)

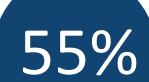

Transportation

Community \& Health Care

$54 \%$
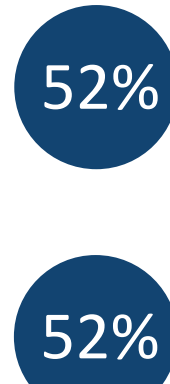

$52 \%$

Community \& Health Care

Community \& Health Care

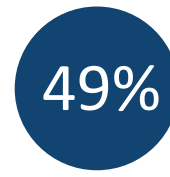

Respectful and helpful hospital and clinic staff

Easy to read traffic signs

Well-maintained hospitals and health care facilities

A variety of health care professionals including specialists

Well-maintained homes and properties 


\section{Bottom Community Features}

(\% Fair/Poor)

45\% Civic Participation \& Employment

A range of flexible job opportunities for older adults
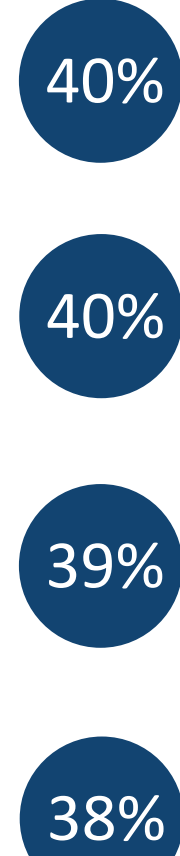

\section{Housing}

\section{Civic Participation \&}

Employment

\section{Civic Participation \&}

Employment

\section{Civic Participation \&}

Employment
Affordable housing options for adults of varying income levels

Policies that ensure older adults can continue to have equal opportunity to work regardless of their age

Job training opportunities for older adults

Jobs that are adapted to meet the needs of people with disabilities 
The majority of Miami-Dade County residents age 50+ believe their community is a good place to age and want to live there independently for as long as possible.

Rating of Current Community

as a Place for People to Live as They Age
Importance of

Remaining in Current Community
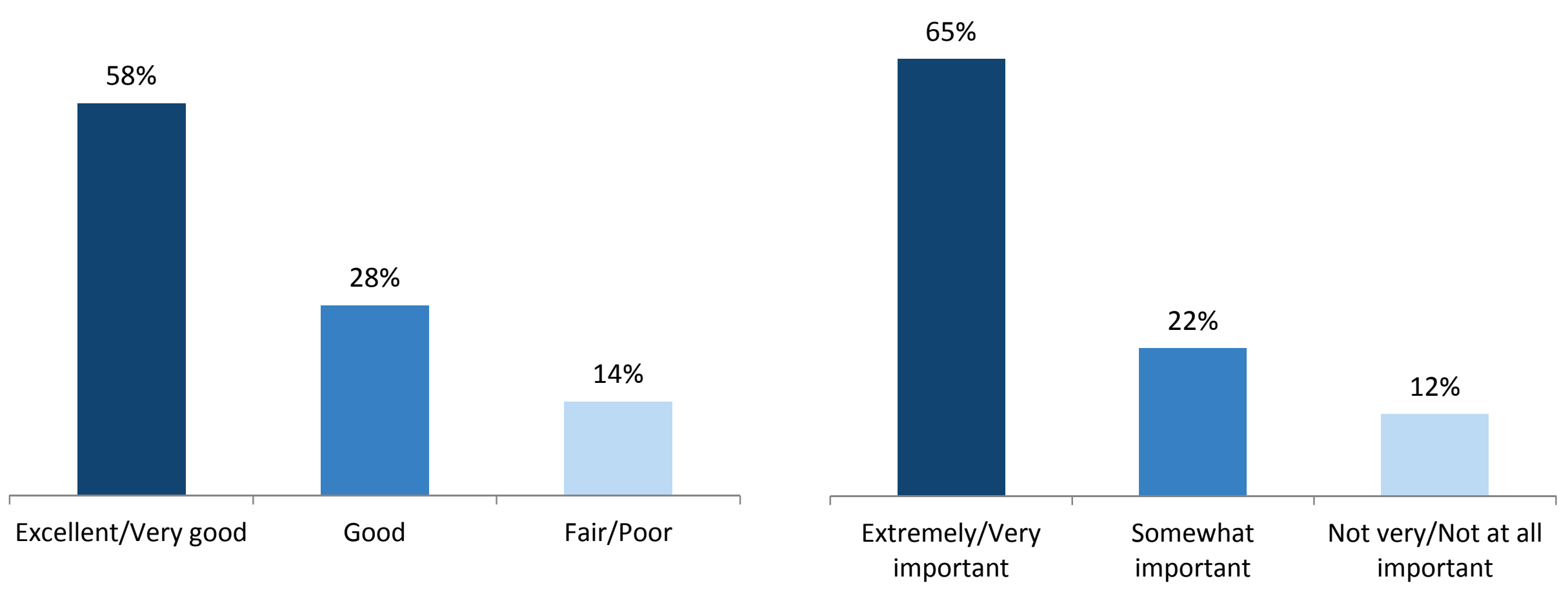

Source: 2017 AARP Age-Friendly Community Survey of Miami-Dade County, FL Residents Age 50+ 


\section{Most Miami-Dade County residents age 50+ own their homes, though nearly one-third are renters.}

\section{Type of Home}

\begin{tabular}{|l|c|}
\hline A single family house & $58 \%$ \\
\hline An apartment & $16 \%$ \\
\hline A condominium/Coop & $13 \%$ \\
\hline A townhouse/Row house & $8 \%$ \\
\hline $\begin{array}{l}\text { A two family house } \\
\text { that has two separate living units }\end{array}$ & $3 \%$ \\
\hline Senior housing/Assisted living facility & $2 \%$ \\
\hline A mobile home & $1 \%$ \\
\hline Other & $0 \%$ \\
\hline
\end{tabular}

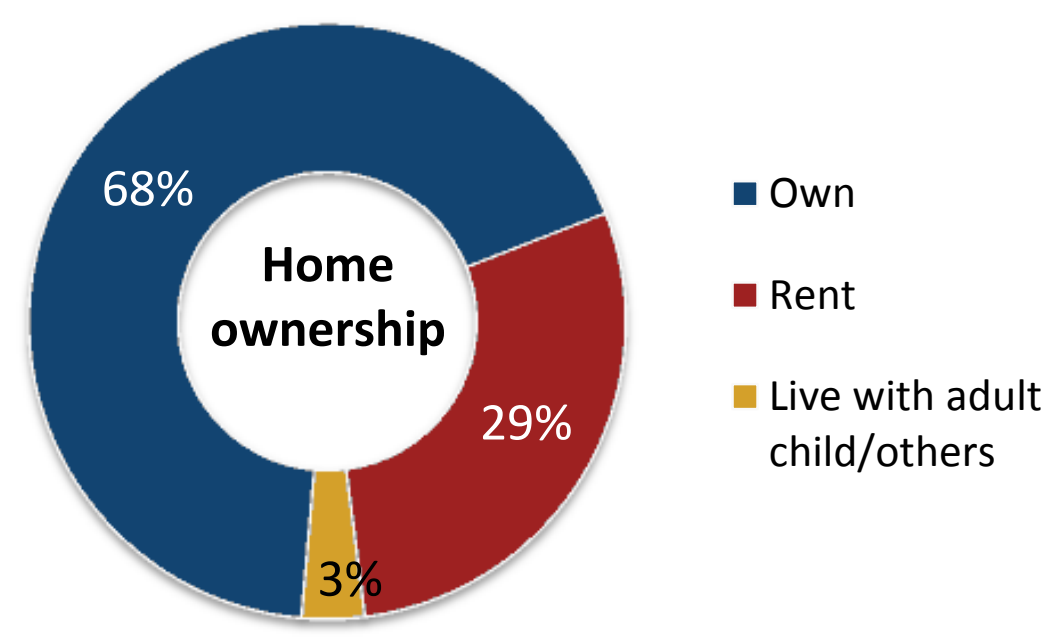

$68 \%$ of respondents say remaining in their current home is extremely/very important.
$2.24 \%$ of respondents $\lambda$ say they need to make major repairs, home modifications, or changes 
Miami-Dade County residents age 50+ have lived in their home for an average of 19 years and have lived in their community even longer, an average of 24 years.

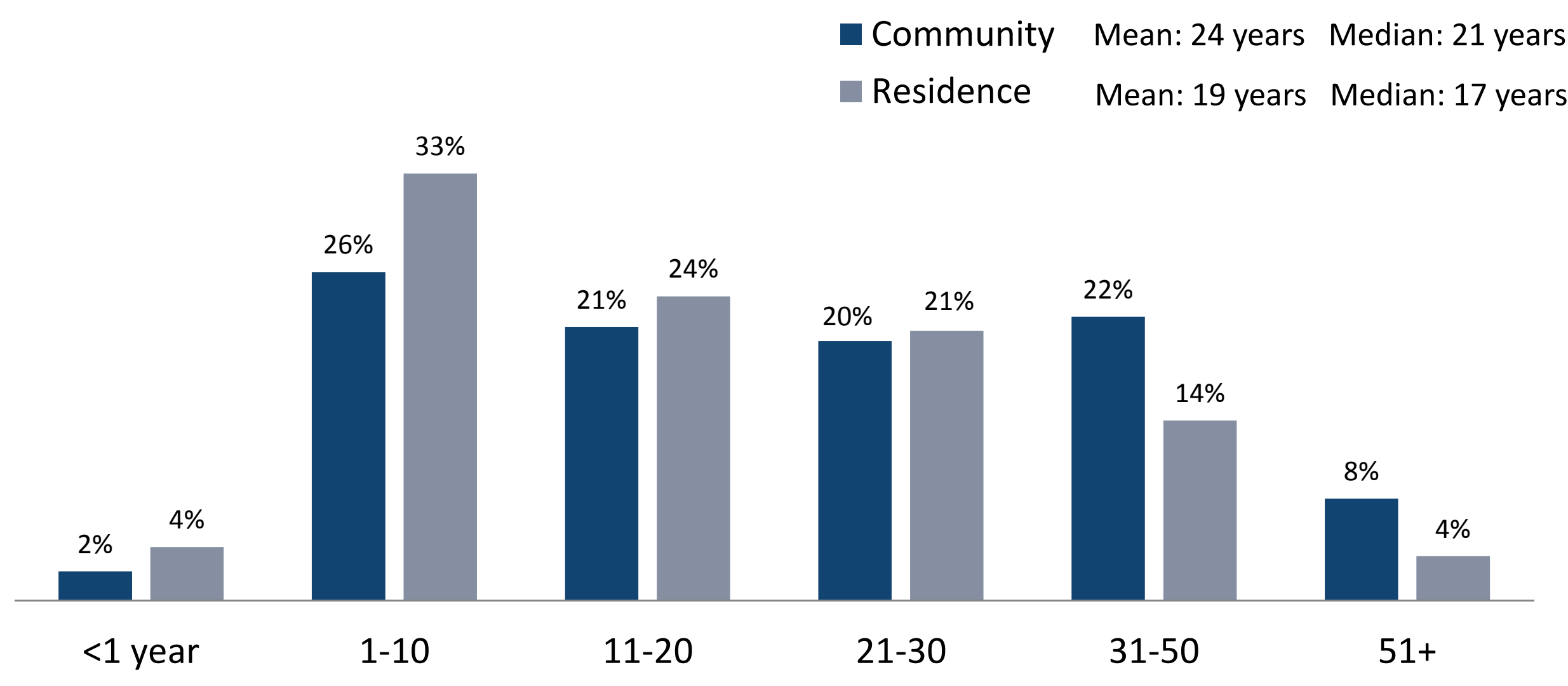


The majority of Miami-Dade County residents age 50+ expect to stay in their home or community as they get older.

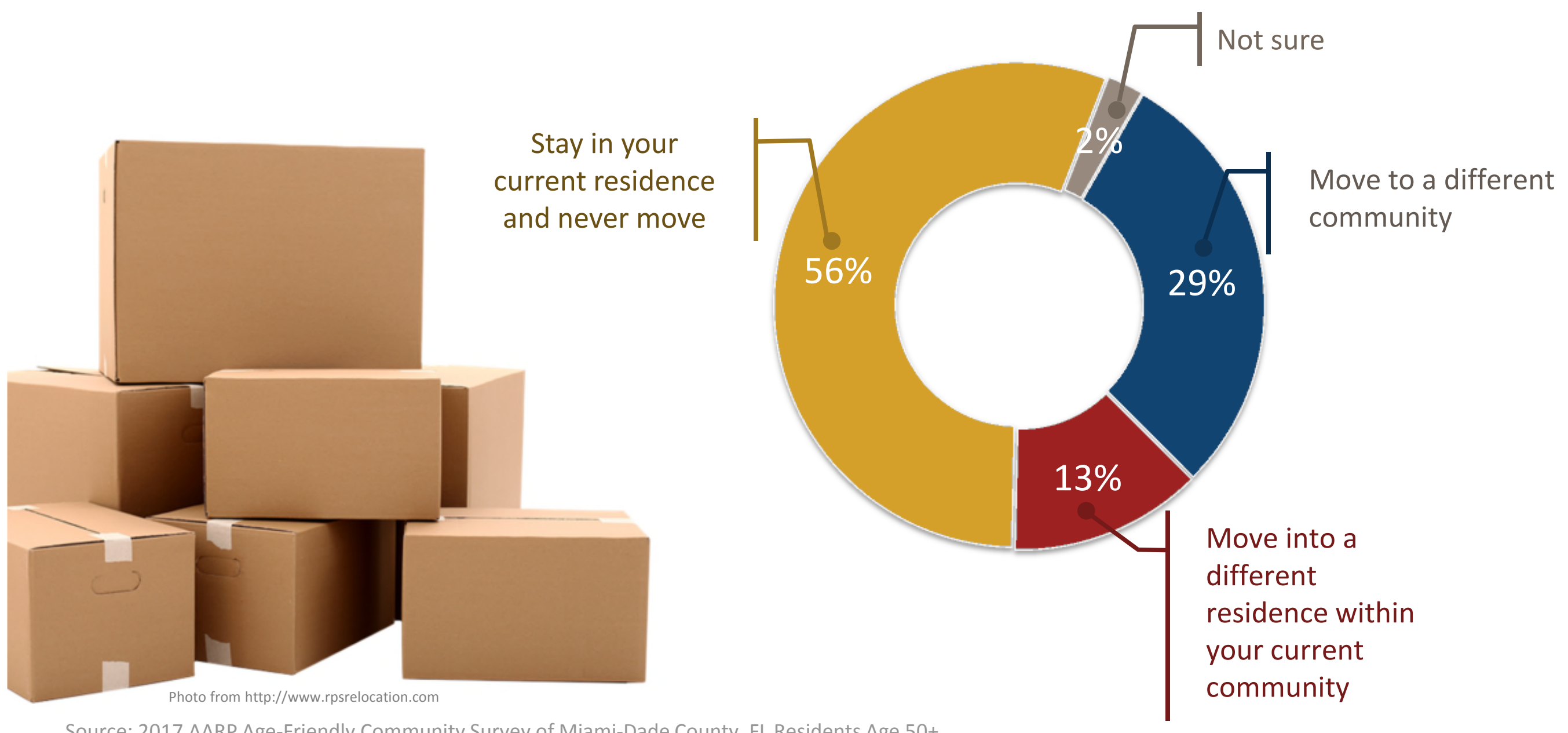




\section{Safety, affordability, and age-friendly housing are influential factors for Miami-Dade County residents age 50+ considering moving when they get older.}

Your personal safety or security concerns

Wanting to live in an area that has a lower cost of living

Wanting a home that will help you live independently as you age

The cost of maintaining your current residence Wanting to be closer to family

Wanting to move to an area that has better health care facilities

Wanting to live in an area with better social opportunities

Needing more access to public transportation

Wanting a smaller size home

Wanting to live in a different climate

Wanting a larger size home
- A major factor $\square$ A minor factor $\square$ Not a factor at all

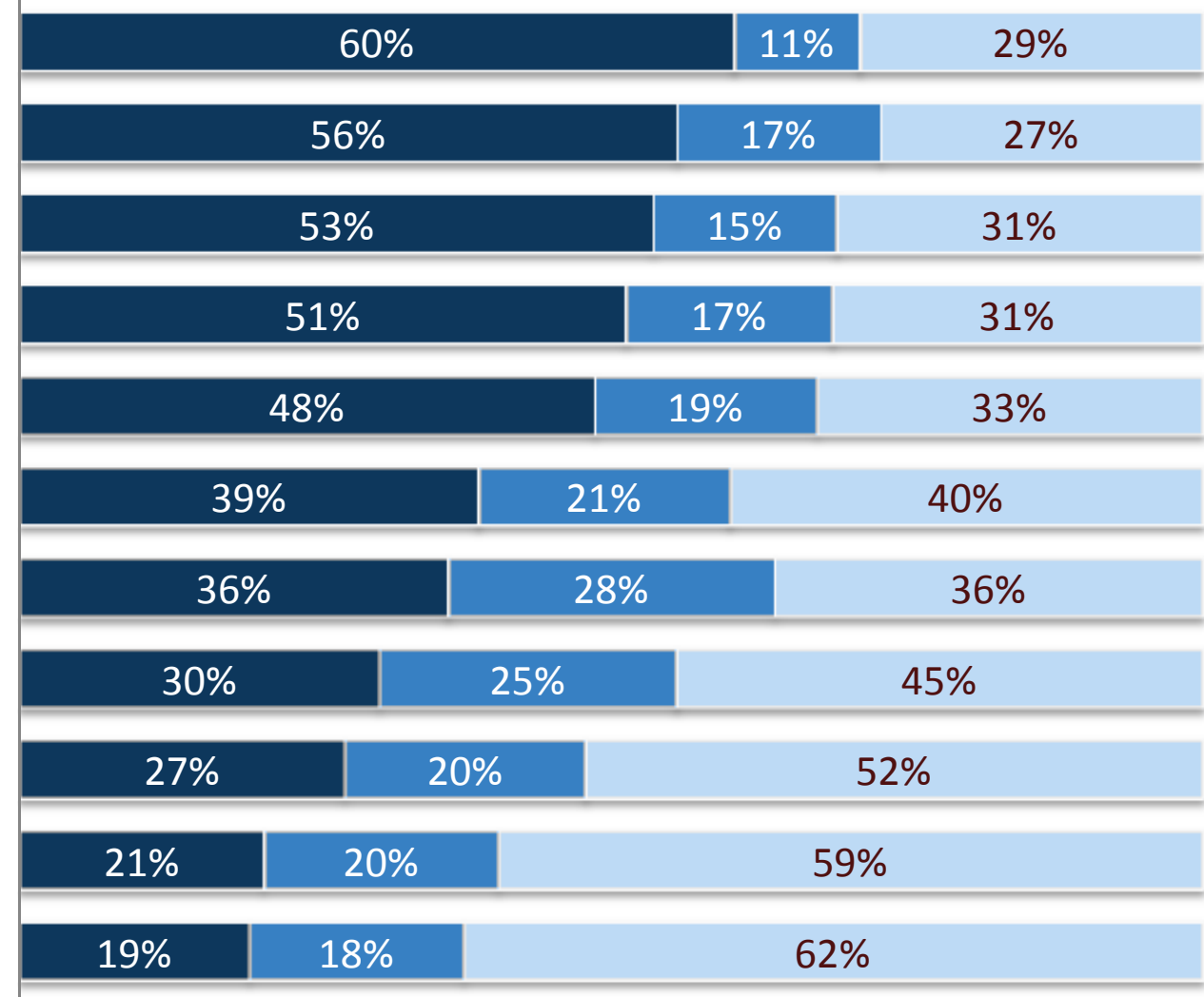




\section{Miami-Dade County residents age $50+$ rate their community positively on having well-maintained homes and properties.}

$\square$ Excellent/Very good $\square$ Good $\square$ Fair/Poor $\square$ Does not exist in the community $\square$ Not sure/Refused

Well-maintained homes and properties

Seasonal services for low-income and older adults (e.g., lawn work)

Home modification and repair contractors

A home repair service for low-income and older adults

Accessibility of homes (e.g., a no step entrance, wider doorways, grab bars in bathrooms, \& first floor bedrooms and bathrooms)

Well-maintained, safe low-income housing

Affordable housing options for adults of varying income levels

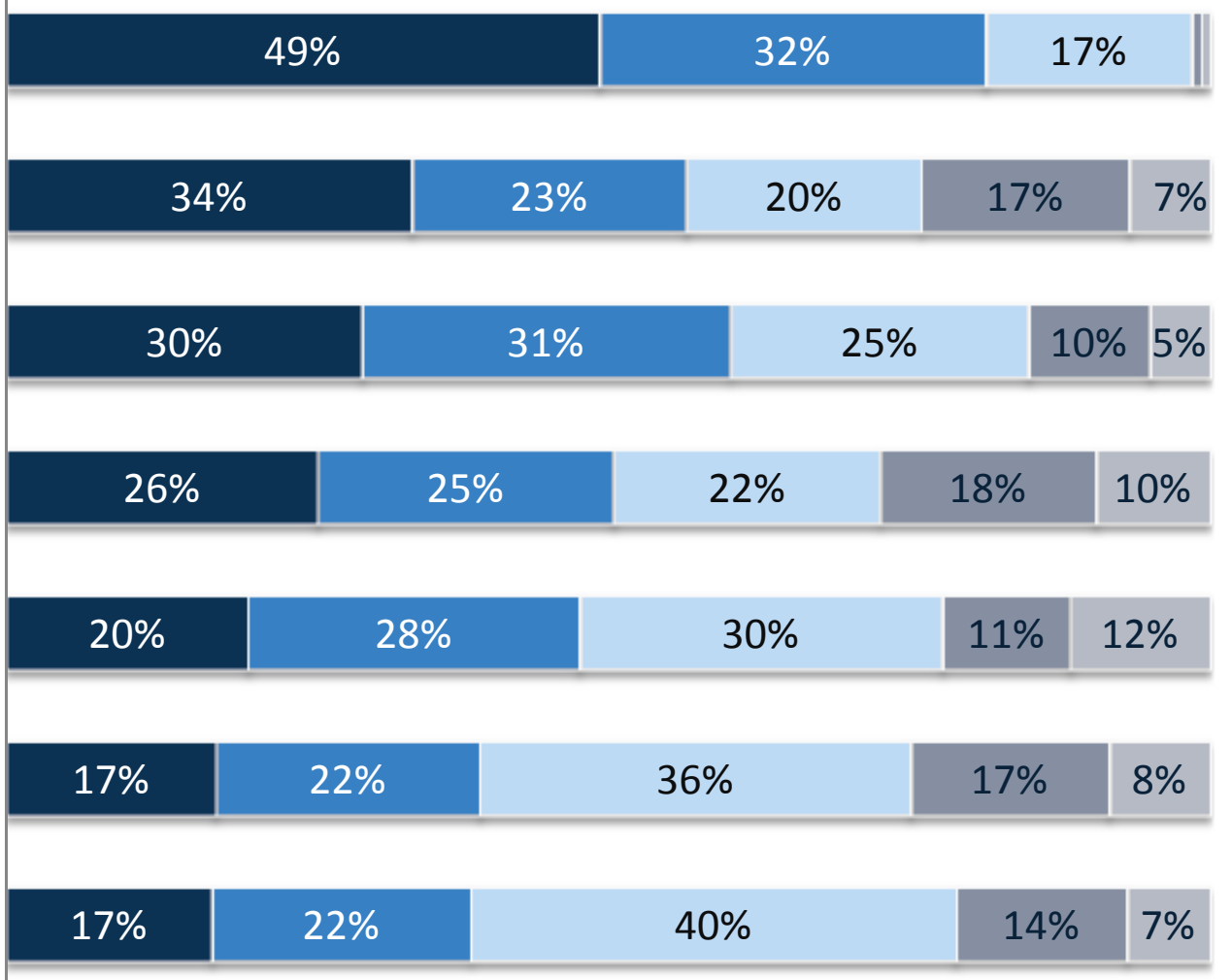




\section{Miami-Dade County residents age 50+ rate their community excellent to good at having safe and accessible sidewalks as well as well-maintained, safe parks.}

- Excellent/Very good $\square$ Good $\square$ Fair/Poor $\square$ Does not exist in community $\square$ Not sure/Refused

Safe and accessible sidewalks

\begin{tabular}{|c|c|c|c|}
\hline $46 \%$ & $26 \%$ & $24 \%$ & $4 \%$ \\
\hline & & & \\
\hline $45 \%$ & $34 \%$ & $14 \%$ & $6 \%$ \\
\hline $41 \%$ & $31 \%$ & $20 \%$ & $7 \% 2 \%$ \\
\hline
\end{tabular}

Accessible public buildings and spaces including restrooms

Enough benches in public areas (e.g., parks, sidewalks, public buildings)

Separate pathways for bicyclists and pedestrians

\begin{tabular}{|c|c|c|c|}
\hline $36 \%$ & $25 \%$ & $23 \%$ & $10 \% 5 \%$ \\
\hline $30 \%$ & $27 \%$ & $34 \%$ & $8 \% 2 \%$ \\
\hline $27 \%$ & $21 \%$ & $33 \%$ & $18 \%$ \\
\hline $24 \%$ & $21 \%$ & $36 \%$ & $13 \%$ \\
\hline
\end{tabular}

Neighborhood watch programs

$24 \%$ 
Most Miami-Dade County residents age 50+ drive themselves to get around their community; they also use a wide variety of other transportation methods.

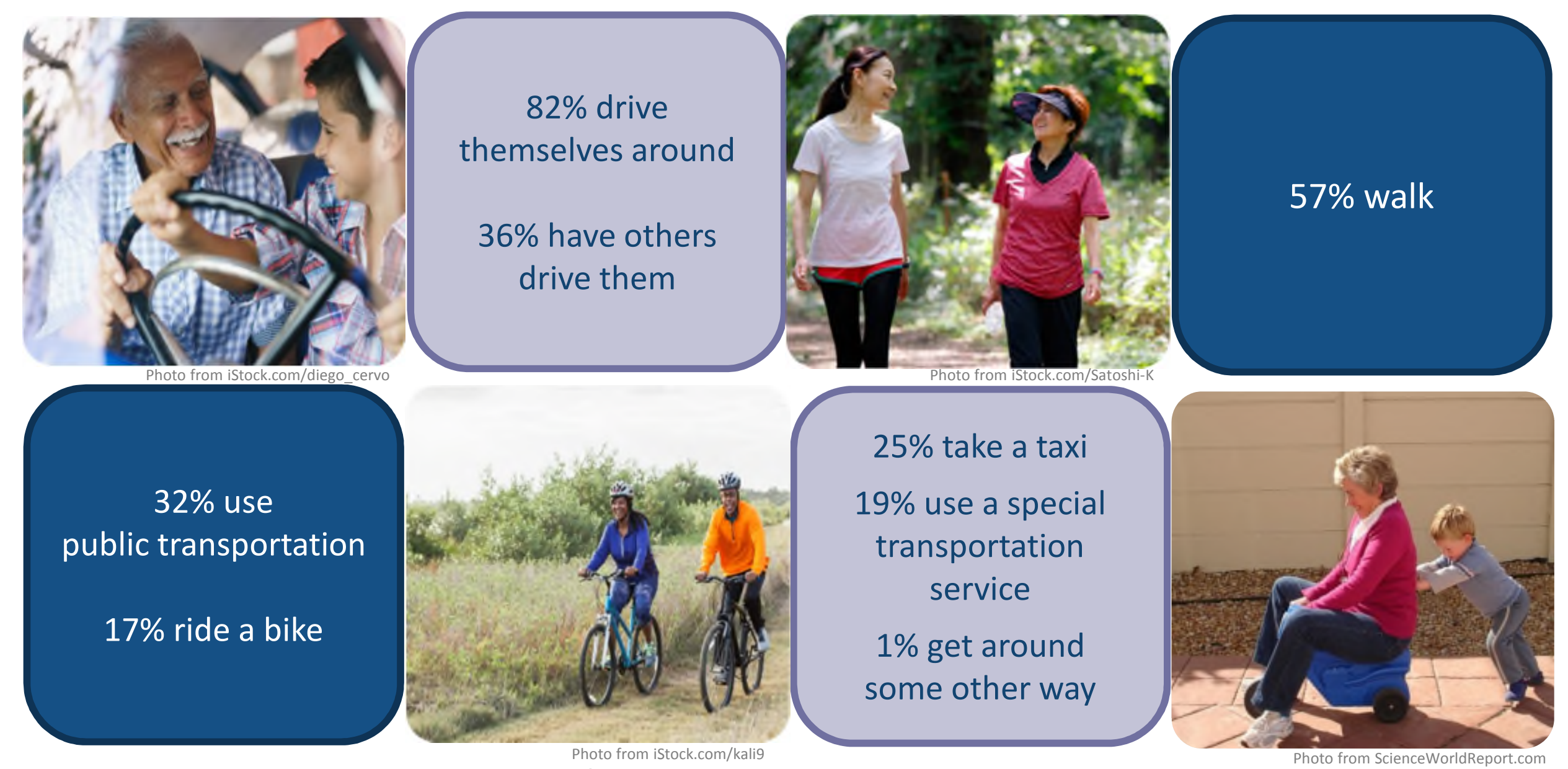

Question: How do you usually get around your community for things like shopping, visiting the doctor, running errands, or other things?

Source: 2017 AARP Age-Friendly Community Survey of Miami-Dade County, FL Residents Age 50+ 


\section{Miami-Dade County residents age $50+$ rate their community excellent to good on having easy to read traffic signs and well-maintained, safe streets with enforced speed limits.}

\author{
- Excellent/Very good $\quad$ Good \\ Easy to read traffic signs \\ Well-maintained streets \\ Enforced speed limits
}

Well-lit, accessible, safe streets and intersections for all users

Conveniently located public parking lots and areas to park

Audio and visual pedestrian crossings

Affordable public parking

Driver education or refresher courses

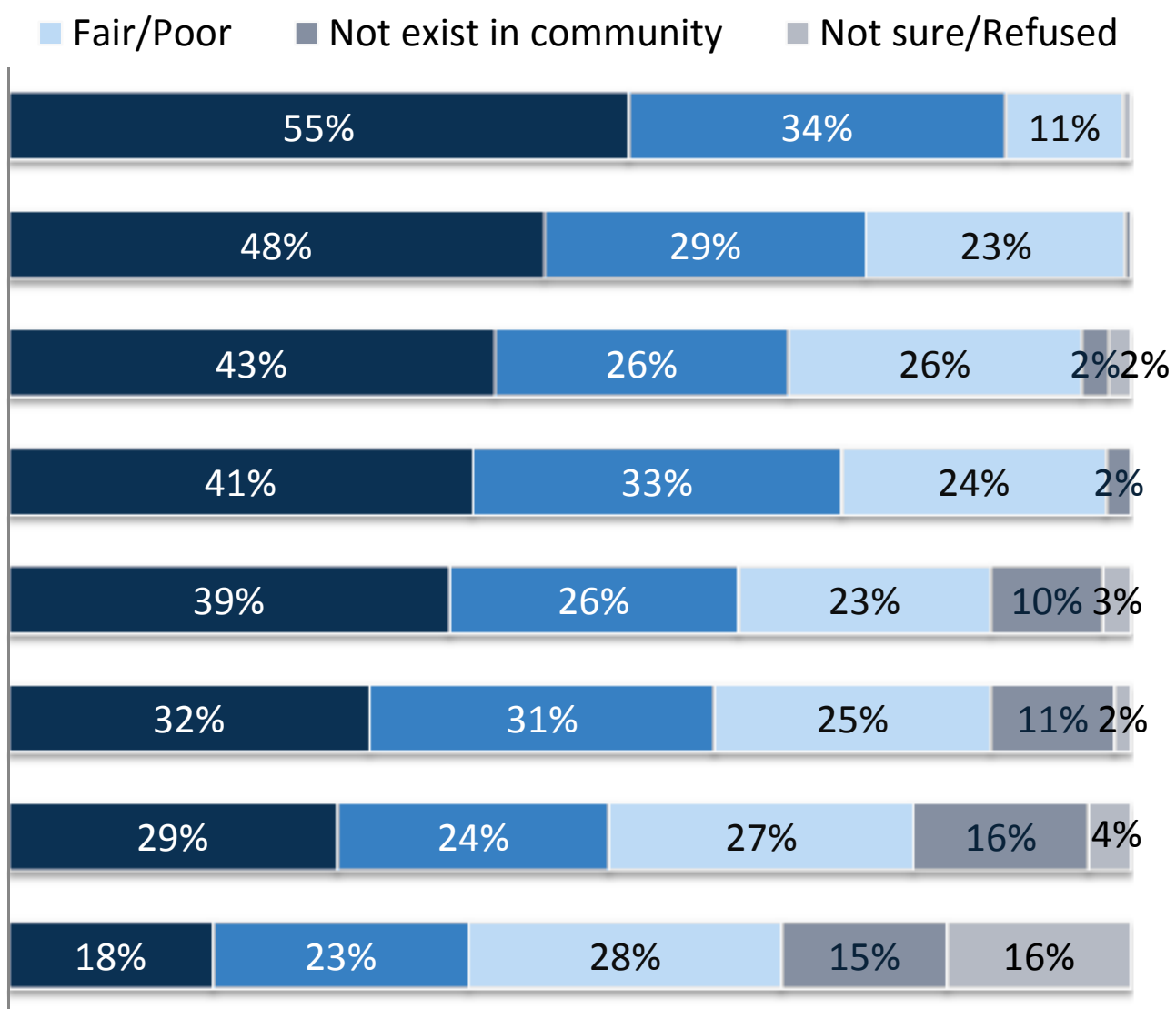




\section{Miami-Dade County residents age 50+ feel their community offers excellent to good special transportation options and well- maintained, safe, convenient, and affordable public transportation.}

\begin{tabular}{|c|c|c|c|c|}
\hline - Excellent/Very good $\quad$ Good & Fair/Poor & Not exist in community & $\square$ Not sur & e/Refused \\
\hline Well-maintained public transportation vehicles & $35 \%$ & $35 \%$ & $20 \%$ & $2 \% 8 \%$ \\
\hline Safe and accessible public transportation stops or areas & $35 \%$ & $30 \%$ & $25 \%$ & $3 \% 7 \%$ \\
\hline Affordable public transportation & $32 \%$ & $31 \%$ & $26 \%$ & $3 \% 8 \%$ \\
\hline $\begin{array}{l}\text { Special transportation services for people with limited physical } \\
\text { functioning }\end{array}$ & $32 \%$ & $34 \%$ & $20 \%$ & $7 \% \quad 9 \%$ \\
\hline Accessible and convenient public transportation & $31 \%$ & $34 \%$ & $28 \%$ & $3 \% 4 \%$ \\
\hline Timely public transportation & $29 \%$ & $32 \%$ & $29 \%$ & $2 \% 8 \%$ \\
\hline
\end{tabular}




\section{About half of Miami-Dade County residents age 50+ rate their} community excellent to very good on having a variety of helpful and respectful health care professionals who speak different languages.

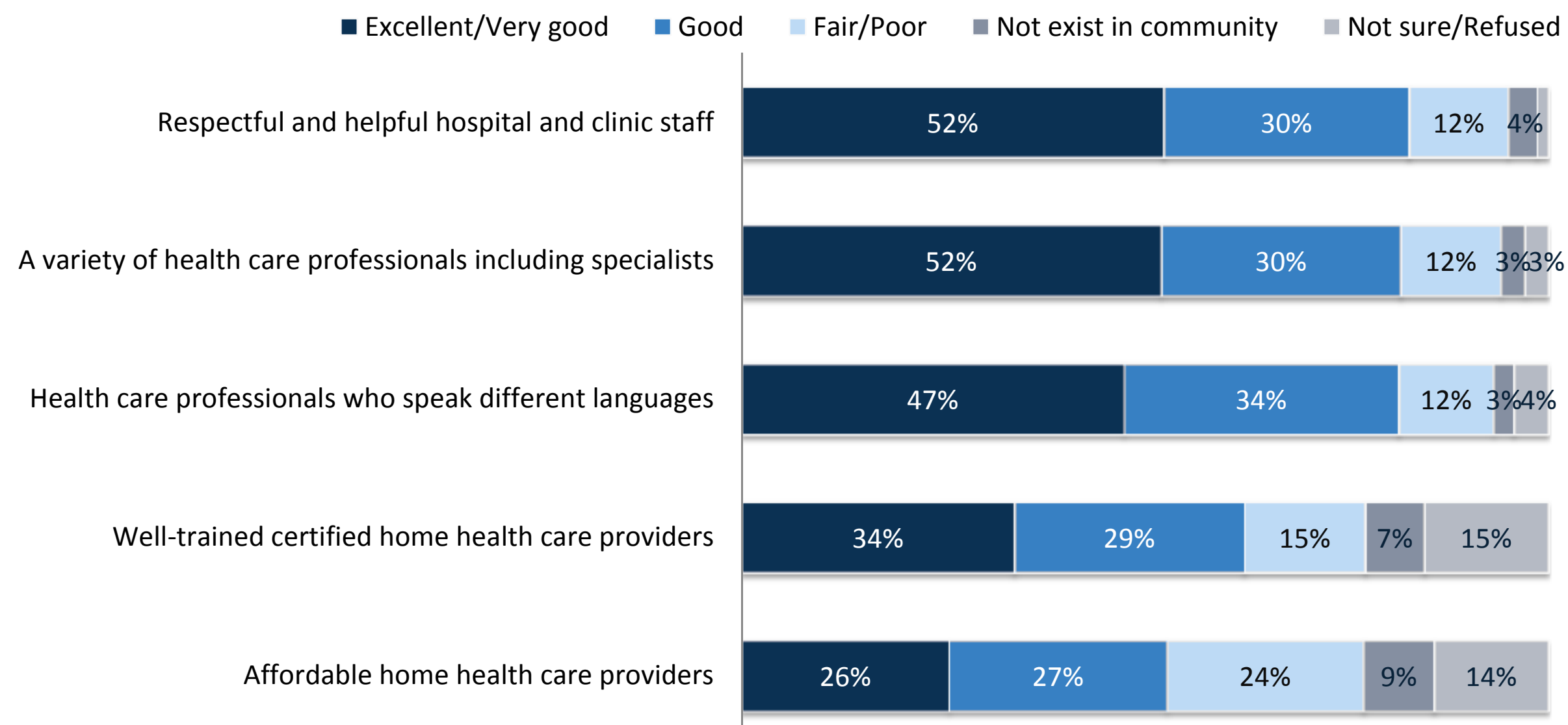




\section{About half of Miami-Dade County residents age 50+ rate their community excellent to very good on having well-maintained health care facilities in convenient locations.}

Excellent/Very good $\quad$ Good $\quad$ Fair/Poor $\quad$ Not exist in community $\square$ Not sure/Refused

Well-maintained hospitals and health care facilities

Conveniently located emergency care centers

Easily understandable and helpful local hospital/ clinic answering services

Conveniently located health and social services

Affordable fitness activities specifically geared towards older adults

Affordable health and wellness programs and classes

A service that provides people to help seniors easily find and access health and supportive services

Affordable home care services (e.g., personal care and housekeeping)

\begin{tabular}{|c|c|c|c|c|}
\hline $54 \%$ & & & & $\% 3 \%$ \\
\hline $48 \%$ & $31 \%$ & & $15 \%$ & $4 \% 2 \%$ \\
\hline $38 \%$ & $33 \%$ & $18 \%$ & 4 & $\% 8 \%$ \\
\hline $37 \%$ & $30 \%$ & $22 \%$ & & $\% 7 \%$ \\
\hline
\end{tabular}

\begin{tabular}{|c|c|c|c|c|}
\hline $31 \%$ & $27 \%$ & $25 \%$ & $7 \%$ & $11 \%$ \\
\hline $27 \%$ & $27 \%$ & $24 \%$ & $10 \%$ & $13 \%$ \\
\hline $26 \%$ & $27 \%$ & $26 \%$ & $8 \%$ & $12 \%$ \\
\hline $22 \%$ & $26 \%$ & $27 \%$ & $10 \%$ & $16 \%$ \\
\hline
\end{tabular}




\section{Miami-Dade County residents age 50+ say their community has a variety of affordable social activities at convenient locations.}

Excellent/Very good $\square$ Good $\square$ Fair/Poor $\square$ Not exist in community $\square$ Not sure/Refused

Conveniently located entertainment venues

A variety of cultural activities for diverse populations

Continuing education classes or social clubs to pursue new interests, hobbies or passions

Activities that involve both younger and older people

Activities that are affordable to all residents

Activities that offer senior discounts

Local schools that involve older adults in events and activities

Activities geared specifically towards older adults

\begin{tabular}{|c|c|c|c|c|}
\hline $32 \%$ & $26 \%$ & $30 \%$ & \multicolumn{2}{|c|}{$7 \% \quad 6 \%$} \\
\hline $31 \%$ & $24 \%$ & $29 \%$ & $9 \%$ & $8 \%$ \\
\hline $27 \%$ & $25 \%$ & $29 \%$ & $10 \%$ & $10 \%$ \\
\hline $25 \%$ & $24 \%$ & $33 \%$ & $7 \%$ & $10 \%$ \\
\hline $24 \%$ & $24 \%$ & $35 \%$ & $8 \%$ & $10 \%$ \\
\hline $24 \%$ & $24 \%$ & $31 \%$ & $7 \%$ & $13 \%$ \\
\hline $24 \%$ & $22 \%$ & $31 \%$ & $10 \%$ & $13 \%$ \\
\hline $22 \%$ & $25 \%$ & $33 \%$ & $10 \%$ & $10 \%$ \\
\hline
\end{tabular}




\section{Miami-Dade County residents age $50+$ give mixed ratings for their community in terms of volunteer activities.}

\begin{tabular}{|c|c|c|c|c|c|}
\hline \multirow[b]{2}{*}{$\begin{array}{l}\text { Opportunities for older adults to participate in decision making bodies } \\
\text { (e.g., community councils or committees) }\end{array}$} & Fair/Poor & \multicolumn{2}{|c|}{ Not exist in community } & \multicolumn{2}{|c|}{$\square$ Not sure/Refused } \\
\hline & $22 \%$ & $24 \%$ & $30 \%$ & $14 \%$ & $10 \%$ \\
\hline A range of volunteer activities to choose from & $20 \%$ & $26 \%$ & $30 \%$ & $12 \%$ & $12 \%$ \\
\hline Easy to find information on available local volunteer opportunities & $20 \%$ & $24 \%$ & $32 \%$ & $12 \%$ & $13 \%$ \\
\hline $\begin{array}{l}\begin{array}{l}\text { Volunteer training opportunities to help people perform better in their } \\
\text { volunteer roles }\end{array}\end{array}$ & $18 \%$ & $23 \%$ & $30 \%$ & $15 \%$ & $15 \%$ \\
\hline Transportation to and from volunteer activities & $15 \%$ & $21 \%$ & $32 \%$ & $16 \%$ & $16 \%$ \\
\hline
\end{tabular}




\section{A plurality of Miami-Dade County residents age 50+ rate their community fair or poor in terms of employment opportunities.}

\begin{tabular}{|c|c|c|c|c|c|}
\hline \multirow[b]{2}{*}{$\begin{array}{c}\text { Policies that ensure older adults can continue to have equal } \\
\text { opportunity to work regardless of their age }\end{array}$} & \multicolumn{2}{|c|}{ Fair/Poor } & Not exist in community & \multicolumn{2}{|c|}{$\square$ Not sure/Refused } \\
\hline & $17 \%$ & $20 \%$ & $40 \%$ & $12 \%$ & $12 \%$ \\
\hline hat are adapted to meet the needs of people with disabilities & $17 \%$ & $20 \%$ & $38 \%$ & $11 \%$ & $14 \%$ \\
\hline A range of flexible job opportunities for older adults & $13 \%$ & $18 \%$ & $45 \%$ & $11 \%$ & $14 \%$ \\
\hline Job training opportunities for older adults & $9 \%$ & $22 \%$ & $39 \%$ & $15 \%$ & $15 \%$ \\
\hline
\end{tabular}


The majority of Miami-Dade County residents age 50+ rate their community positively on having free access to computers and the Internet in public places and community information that is available in different languages; however, having information for residents with limited mobility receives more negative ratings.

Excellent/Very good $\quad$ Good $\quad$ Fair/Poor $\quad$ Not exist in community $\square$ Not sure/Refused

Free access to computers and the Internet in public places

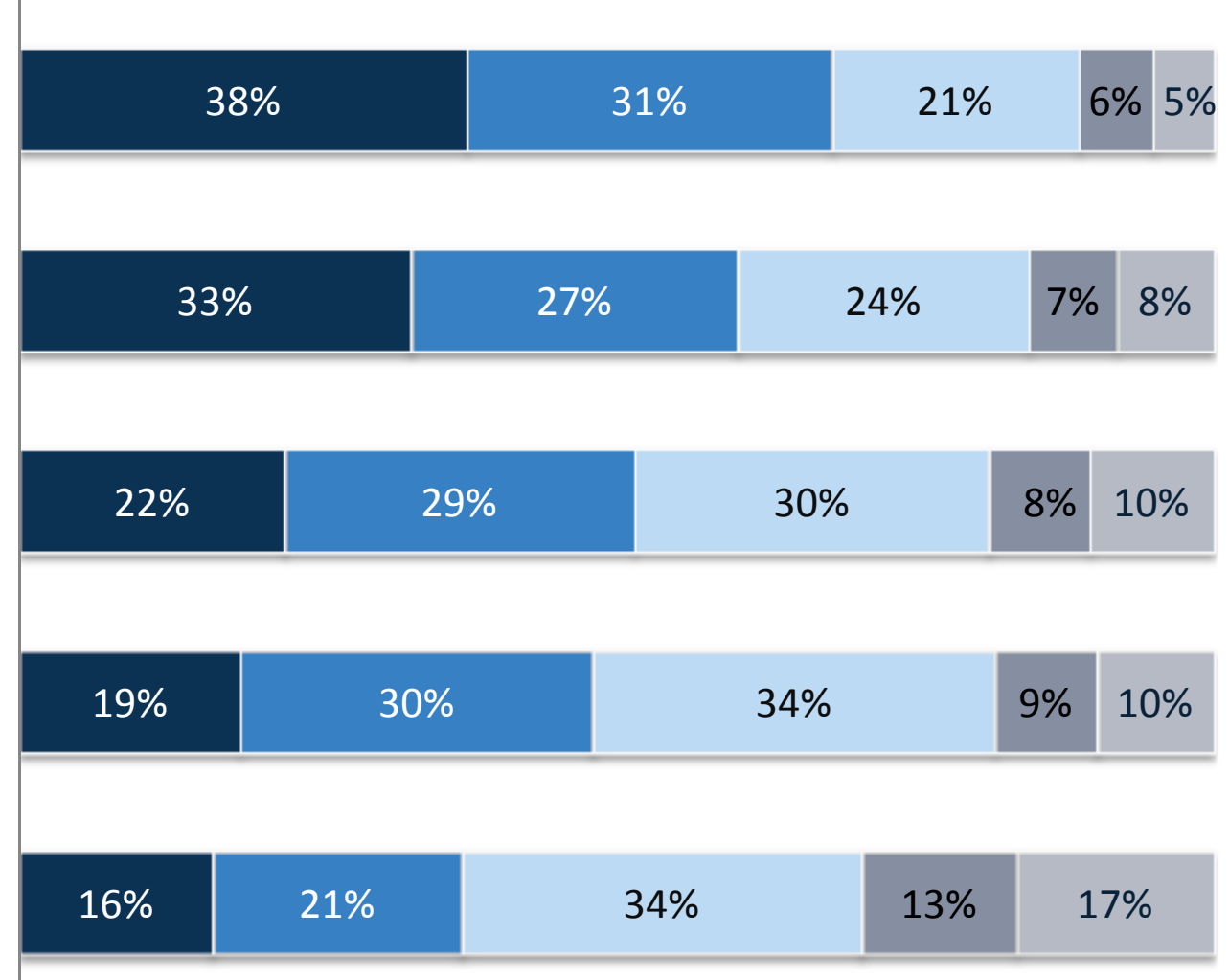

Community information that is available in different languages

Access to community information in one central source

Clearly displayed printed community information with large lettering

Community information that is delivered in person to people who may have difficulty of may not be able to leave their home 


\section{Respondent Profile: Demographics}

\begin{tabular}{|l|r|l|l|}
\hline \multicolumn{2}{|l|}{ Gender } & \multicolumn{2}{l|}{ Age } \\
\hline Male & $45 \%$ & $50-54$ & $22 \%$ \\
\hline Female & $55 \%$ & $55-64$ & $35 \%$ \\
\hline AARP Membership & $65-74$ & $23 \%$ \\
\hline Yes & $22 \%$ & $75-84$ & $14 \%$ \\
\hline No & $76 \%$ & 85 or older & $6 \%$ \\
\hline
\end{tabular}

\begin{tabular}{l|c|}
\hline \multicolumn{2}{|c|}{ Race/Ethnicity* } \\
\hline White or Caucasian & $17 \%$ \\
\hline Black & $15 \%$ \\
\hline Asian & $1 \%$ \\
\hline $\begin{array}{l}\text { Native American } \\
\text { or Alaskan Native }\end{array}$ & $<1 \%$ \\
\hline $\begin{array}{l}\text { Native Hawaiian } \\
\text { or Pacific Islander }\end{array}$ & $0 \%$ \\
\hline $\begin{array}{l}\text { Hispanic } \\
\text { Other }\end{array}$ & $66 \%$ \\
\hline
\end{tabular}

\section{Marital Status}

\begin{tabular}{|l|c|}
\hline Single, never married & $15 \%$ \\
\hline Married & $45 \%$ \\
\hline $\begin{array}{l}\text { Not married, living with your } \\
\text { partner or significant other }\end{array}$ & $4 \%$ \\
\hline Separated & $3 \%$ \\
\hline Divorced & $18 \%$ \\
\hline Widowed & $14 \%$ \\
\hline
\end{tabular}

\section{Disability Status}

\section{Health Status}

\begin{tabular}{|l|l|}
\hline Excellent/Very good & $42 \%$ \\
\hline Good & $36 \%$ \\
\hline Fair/Poor & $22 \%$ \\
\hline
\end{tabular}

Yes, myself

Yes, my spouse or partner

Yes, both myself and my spouse or partner

No

\begin{tabular}{|l|c|}
\hline Yes, myself & $19 \%$ \\
\hline Yes, my spouse or partner & $3 \%$ \\
\hline Yes, both myself and my spouse or partner & $2 \%$ \\
\hline No & $73 \%$ \\
\hline
\end{tabular}

*Based on total number of survey respondents.

Source: 2017 AARP Age-Friendly Community Survey of Miami-Dade County, FL Residents Age 50+ 


\section{Respondent Profile: Socioeconomic \& Voting}

\begin{tabular}{l|l|}
\hline \multicolumn{2}{|l|}{ Education } \\
\hline $\begin{array}{l}\text { O to 12th grade, } \\
\text { but with no diploma }\end{array}$ & $7 \%$ \\
$\begin{array}{l}\text { High school graduate } \\
\text { or equivalent }\end{array}$ & $17 \%$ \\
\hline $\begin{array}{l}\text { Post high school education, } \\
\text { but with no degree }\end{array}$ & $14 \%$ \\
\hline $\begin{array}{l}2 \text { year degree } \\
\text { (Associate's Degree) }\end{array}$ & $16 \%$ \\
\hline $\begin{array}{l}4 \text { year degree } \\
\text { (Bachelor's Degree) }\end{array}$ & $24 \%$ \\
\hline $\begin{array}{l}\text { Post graduate study, } \\
\text { but with no degree }\end{array}$ & $5 \%$ \\
\hline $\begin{array}{l}\text { Graduate } \\
\text { or professional degree }\end{array}$ & $16 \%$ \\
\hline \begin{tabular}{l} 
Voting Behavior \\
\hline $\begin{array}{l}\text { Always } \\
\text { Most of the time }\end{array}$
\end{tabular} & $10 \%$ \\
\hline $\begin{array}{l}\text { About half of the time } \\
\text { Seldom }\end{array}$ & $19 \%$ \\
\hline Never & $6 \%$ \\
\hline
\end{tabular}

\begin{tabular}{|l|c|}
\hline \multicolumn{2}{|l|}{ Employment Status } \\
\hline Self-employed full-time & $10 \%$ \\
\hline Self-employed part-time & $3 \%$ \\
\hline Employed full-time & $22 \%$ \\
\hline Employed part-time & $8 \%$ \\
\hline Retired and not working at all & $41 \%$ \\
\hline \begin{tabular}{l} 
Unemployed and looking for work \\
\hline $\begin{array}{l}\text { Not in the labor force for other } \\
\text { reasons }\end{array}$
\end{tabular} & $6 \%$ \\
\hline
\end{tabular}

\section{Political Party}

\begin{tabular}{|l|c|}
\hline Democrat & $42 \%$ \\
\hline Republican & $29 \%$ \\
\hline Independent & $21 \%$ \\
\hline Something else & $<1 \%$ \\
\hline
\end{tabular}

\begin{tabular}{|l|c|}
\hline \multicolumn{2}{|c|}{ Income } \\
\hline$<\$ 10,000$ & $12 \%$ \\
\hline$\$ 10,000-\$ 19,999$ & $14 \%$ \\
\hline$\$ 20,000-\$ 29,999$ & $11 \%$ \\
\hline$\$ 30,000-\$ 49,999$ & $15 \%$ \\
\hline$\$ 50,000-\$ 74,999$ & $17 \%$ \\
\hline$\$ 75,000-\$ 99,999$ & $10 \%$ \\
\hline$\$ 100,000-\$ 149,999$ & $7 \%$ \\
\hline$\$ 150,000+$ & $4 \%$ \\
\hline
\end{tabular}

Source: 2017 AARP Age-Friendly Community Survey of Miami-Dade County, FL Residents Age 50+ 


\section{Survey Methodology:}

- A telephone survey was commissioned by AARP to assess public opinion among Miami-Dade County residents age 50+ about age-friendly and livable community topics in MiamiDade County.

- Telephone interviewing was conducted by Alan Newman Research from July 7th to July 21st 2017.

- A total of 525 interviews were conducted. The margin of error for this sample is $\pm 4.3 \%$.

- The sample utilized RDD landline and cell phone records. 


\section{Contact Information:}

- This deck, the annotated survey, the methodology report, and an infographic can be accessed at: www.aarp.org/AgeFriendlyCommunities

- For more information about age-friendly work in MiamiDade County, please contact Laura Cantwell, AARP Florida, at Icantwell@aarp.org.

- For more information about the survey, please contact Joanne Binette, AARP Research, at jbinette@aarp.org. 